\title{
Anti-IL1 therapy in patients with refractory FMF living inGermany
}

\author{
B Buhl*, H-M Lorenz, N Blank \\ From 8th International Congress of Familial Mediterranean Fever and Systemic Autoinflammatory Diseases \\ Dresden, Germany. 30 September - 3 October 2015
}

\section{Introduction}

About $10-20 \%$ of patients with familial Mediterranean fever (FMF) show an inadequate response to colchicine. Patients with colchicine-resistant FMF with or without AA-Amyloidosis can be treated with Interleukin-1 (IL-1)-inhibiting drugs.

\section{Objective}

We report our experience in adult patients with colchicine-resistant FMF who were treated with anakinra or canakinumab.

\section{Patients and methods}

Demographic data, clinical and laboratory parameters, MEFV mutations, patient reported outcomes and physician global health were analyzed in 15 patients treated with anakinra or canakinumab.

\section{Results}

Within our cohort of 160 adult patients with FMF, we identified 15 patients ( 4 female and 11 male) who were treated with anakinra $(n=13)$ or canakinumab $(n=2)$. Twelve of 15 patients (80\%) were of turkish-armenian ancestry. The median FMF severity score was 8 (range 5-14). Patients carrying two high-penetrance MEFV mutations (M694V or M680I) had a severity score of $9(8 / 15=53 \%)$. Patients with a single high penetrance mutation had a severity score of $11(3 / 15=20 \%)$. Four patients $(4 / 15=27 \%)$ had no MEFV mutations and the FMF severity score was $7.5(\mathrm{p}=0.2)$. FMF-related AA amyloidosis was diagnosed in 6 patients $(40 \%)$ and the median FMF severity score was 10 compared to a severity score of 7 in 9 patients without amyloidosis $(60 \%)$ $(\mathrm{p}=0.3)$. Anakinra was used continuously in 13 patients and in 2 patients only during attacks. The number of

\footnotetext{
University Hospital Heidelberg, Internal Medicine 5, Division of
} Rheumatology, Heidelberg, Germany

C 2015 Buhl et al. This is an Open Access article distributed under the terms of the Creative Commons Attribution License (http:// creativecommons.org/licenses/by/4.0), which permits unrestricted use, distribution, and reproduction in any medium, provided the original work is properly cited. The Creative Commons Public Domain Dedication waiver (http://creativecommons.org/publicdomain/ zero/1.0/) applies to the data made available in this article, unless otherwise stated.
FMF attacks was significantly reduced by anti-IL1 treatment $(\mathrm{p}=0.0024)$. The patient reported health and the physician reported global health were both improved significantly ( $\mathrm{p}$

\section{Conclusion}

IL-1-blocking therapies are well tolerated and effective in patients with colchicine-resistant FMF. Blocking IL-1 reduced the number and severity of FMF attacks.

Published: 28 September 2015

doi:10.1186/1546-0096-13-S1-P110

Cite this article as: Buhl et al:: Anti-IL1 therapy in patients with

refractory FMF living inGermany. Pediatric Rheumatology 2015

13(Suppl 1):P110.
Submit your next manuscript to BioMed Central

- Convenient online submission

- Thorough peer review

- No space constraints or color figure charges

- Immediate publication on acceptance

- Inclusion in PubMed, CAS, Scopus and Google Scholar

- Research which is freely available for redistribution Submit your manuscript at
www.biomedcentral.com/submit C BioMed Central and take full advantage of: 